
D. S. Asche:
G. O. ОкıкіоLU:
N. D. Gupta and

M. F. NEWMAN

T. K. Shrng:

J. N. WARD:

K. R. Pearson:

\section{Peter LoRIMRR:}

E. S. BARNES and

T. J. Drckson:

T. M. GAGEN and Z. JANKo: Finite simple groups with nilpotent third maximal subgroups WARREN BRISLEY:

On varieties of metabelian p-groups and their laws

KenNETh D. MAgill JR:

P. D. FINCH:

P. ERDös, A. SARKöZY, E. Szemerédi:

L. J. Gleeson:

SADAYUKI YAMAMURO:

A. Figh-Talamanca and G. I. GAUDRY:

D. B. GOODNER:

H. L. MANOCHA and
B. L. Sharma:

R. R. LAXTON:

B. BRAINERD and

R. E. EdWARds:

Hermann Heineken and

Peter M. Neumann:

TEKLA LeWIN:

Kenneth D. Magill, JR:

ROBERT W. GILMER, JR and William J. Heinzer:

Paul M. Weichsel:

H. A. BUCHDAHL:

H. A. BUCHDAHL:

Sahib Ram Mandan

B. BRAINERD and

R. E. EDWARDS:

F. Cunningham, JR:

Minimal dependent sets

On integral operators associated with Poisson transforms and the operator $H_{\alpha}$

On metabelian groups

Rational polygons

Involutory automorphisms of groups of odd order

Interval semirings on $R_{1}$ with ordinary multiplication

A note on doubly transitive groups

Extreme coverings of $n$-space by spheres

Semigroup structures for families of functions, I. Some homomorphism theorems

On the lattice equivalence of topological spaces

On a theorem of Behrend

Forces motion of a charged particle in a magnetic field

On the spaces of mappings on Banach spaces

Density and representation theorems for multipliers of type $(p, q)$

A converse to Lebesgue's dominated convergence theorem

Summation and infinite series

Linear recurrences of order two

Linear operators which commute with translations, Part I:

Representation theorems

Identical relations and decision procedures for groups

Finitely generated $D$-groups

Semigroup structures for families of functions, II. continuous functions

On the complete integral closure of an integral domain

On metabelian p-groups

On Rotor Calculus, I

On Rotor Calculus, II

Geometry of a simplex inscribed in a normal rational curve

Linear operators which commute with translations, Part II: Applications of the representation theorems

Generalization of a theorem of P. D. Finch on integration of set-functions 


\section{LECTURES ON TENSOR CALCULUS AND DIFFERENTIAL GEOMETRY} J. C. H. Gerretsen

xii. 204 pp. 1962. Cloth Dfl. 27.50 / US $\$ 7.60$ / A. $\$ 6.90$

MATRIX MECHANICS / H.S. Green

With a foreword by Max Born

118 pp. 1965. Cloth Dfl. 19.75 / US $\$ 5.50$ / A. $\$ 4.90$

\section{APPROXIMATE METHODS OF HIGHER ANALYSIS}

L. V. Kantorovich and V. I. Krylov

Translated from the fourth Russian edition by C. D. Benster xvi. 681 pp. 1959. Cloth Dfi. 69.00 / US $\$ 19.25$ / A. $\$ 17.25$

INTRODUCTION TO GENERAL TOPOLOGY / Zlatko P. Mamuziধ

Translated by Leo F. Boron, a.o.

160 pp. 1963. Cloth Dff. 17.50 / US $\$ 4.90$ / A. $\$ 4.40$

\section{THE COLLECTED MATHEMATICAL WORKS OF}

J. H. AND A. G. M. MICHELL / Michell Brothers

Edited by F. W. Niedenfuhr and J. R. M. Radok. With a foreword by Prof. T. M. Cherry 340 pp. 1965. Cloth Dfl. 25.50 / US $\$ 7.10$ / A. $\$ 6.40$

\section{VECTOR SPACES / D.A. Raikov}

Translated from the first Russian edition by Leo F. Boron, a.o.

xii. 190 pp. 1965 . Cloth Dfl. 27.50 / US $\$ 7.60$ / A. $\$ 6.90$

\section{HIGHER MATHEMATICS / I. Suvorov}

Translated by $\mathrm{G}$. Yankovsky

320 pp. 1965. Cloth DfI. 19.75 / US $\$ 5.50$ / A. $\$ 4.90$

METHODS OF A. M. LYAPUNOV AND THEIR APPLICATION / V. I. Zubov Edited by Leo F. Boron, after the memographed translation issue by the Atomic Energy Commission xvi. 263 pp. 1964. Cloth Df. $33.60 /$ US $\$ 9.40 /$ A. $\$ 8.40$

\section{SCIENCE AWAKENING / B. L. van der Waerden}

(Erwachende Wissenschaft I)

Translated from the Dutch by Prof. A. Dresden with additions of the Author.

2nd edition. 134 fig. 28 plates. iv. 306 pp. 1961 . Cloth Dfl. 29.75 / US $\$ 8.75$ / A. $\$ 7.50$

DIE ANFÄNGE DER ASTRONOMIE / B. L. van der Waerden

(Erwachende Wissenschaft II)

32 Bilder. Moderne Sternkarte. 26 Figuren. 289 S. Register. 1965. Deutsch. Leinen Hfl. 47.- / US $\$ 13 .-/$ A. $\$ 11.75$

\section{P. NOORDHOFF LTD. / Scientific publishers}

Order through your supplier or directly from the publisher P. O. Box 39, Groningen, The Netherlands 